\title{
An Assessment of Native Forests in Queensland for the Potential Supply of Small-diameter, Peeler Logs for Spindleless Lathe Rotary-veneer Processing
}

\begin{abstract}
William Leggate, ${ }^{\mathrm{a}, *}$ Robert L. McGavin, ${ }^{\mathrm{a}}$ and Tom Lewis ${ }^{\mathrm{b}}$
Spindleless lathes have shown great potential for the efficient conversion of small native forest logs in Australia. However, a major impediment to the further commercial adoption of this processing approach for native forest small-diameter logs is the absence of reliable and available data on the quantities of logs possibly available and suitable for this purpose. This study undertaken in hardwood and white cypress pine (Callitris glaucophylla) native forests and at sawmills in Queensland, Australia, demonstrated that there are potentially substantial quantities (up to 10.5 $\mathrm{m}^{3}$ per hectare of Crown native hardwood, $14 \mathrm{~m}^{3}$ per hectare of private forest hardwood and 75,000 $\mathrm{m}^{3}$ per year of Crown white cypress pine) logs suitable for spindleless lathe rotary veneer processing. However, access to and utilization of these logs will depend on many factors including accommodating Government policies and log supply agreements; potential alterations in the code of practice for native forest harvesting, silviculture, tree marking and sales practices; diversion of logs from other uses; and development of appropriate log specifications.
\end{abstract}

Keywords: Veneer; Hardwood; Cypress; Peeling; Resource assessment; Forest inventory

Contact information: a: Queensland Department of Agriculture and Fisheries, Horticulture and Forestry Science, Salisbury Research Facility, 50 Evans Road, Salisbury, Queensland 4107 Australia;

b: Queensland Department of Agriculture and Fisheries, Horticulture and Forestry Science, University of the Sunshine Coast, Sippy Downs, Queensland, 4556 Australia;

*Corresponding author: william.leggate@daf.qld.gov.au

\section{INTRODUCTION}

Commercial native forest harvesting in Australia has historically targeted industry's demand for sawlogs to produce sawn timber and pulplogs for pulp and paper production. Other, important traditional uses for native forest logs are utility poles, bridge girders, railway timbers (e.g., sleepers, transoms), piles, fencing, landscaping, and firewood. In the past, the production of veneer-based products from native forests in Australia was mainly confined to sliced, decorative veneer from hardwoods using very large logs and highly sought-after, premium quality species. Until recently, rotary veneer production from native hardwood logs in Australia has also been focused mainly on relatively large logs from trees greater than $40 \mathrm{~cm}$ diameter at breast height over bark (DBHOB). There has also been no commercial production of veneer from the native white cypress pine (Callitris glaucophylla) resource in Australia.

New processing technologies, forest resource changes (i.e., smaller logs and lower qualities), changing market demands, and building practice advancements have strengthened the case for greater conversion of the Australian native forest resource, particularly the smaller-diameter, underutilized log component, into veneer-based products. The changes in processing technology include the emergence of new spindleless 
lathe technology that can efficiently convert logs even smaller than $15 \mathrm{~cm}$ in diameter into veneers (McGavin et al. 2014a; Peng et al. 2014; Leggate et al. 2017; Belleville et al. 2018). There has been a proliferation of these lathe types internationally, but mainly in countries such as China and Vietnam for conversion of small-diameter, plantation acacia and eucalypts (Leggate et al. 2017). Recent research has demonstrated the numerous advantages of veneer-based production over sawing, using spindleless lathes for processing small-diameter logs from plantation hardwood, native hardwood, and native cypress resources in Australia (McGavin et al. 2014a,b, 2015a,b, 2019). This research highlighted the potential to use spindleless lathe veneering technologies to process logs with sizes and qualities previously considered unable to be efficiently processed. The studies have shown that this new approach can process small-diameter logs and is able to yield recovery rates that are higher than what is achieved through other processes such as sawing (McGavin et al. 2014a,b, 2015a,b, 2019).

Even though it might be deemed technically feasible and advantageous to process a component of the Australian native forest hardwood and cypress resource into veneerbased products using spindleless lathes, the commercial feasibility will be impacted if the resource is not available in sufficient quantities and qualities at economically viable locations. Unfortunately, forest inventories undertaken by Government departments and private forestry organizations in Australia do not usually include assessments of log types and quantities suitable for processing with spindleless lathes, particularly for smaller log sizes (less than $30 \mathrm{~cm}$ small end diameter). Existing inventories tend to focus on mainstream current products such as sawlogs. There is currently no published information available on what volume of logs from native forests in Australia would be potentially available that suits processing into rotary veneer with spindleless lathe technology. Recent inventories in the private native forest resource in northern New South Wales and Queensland (Jay 2017; Lewis 2018) show that there is a high proportion of small trees in a given stand (i.e., $>75 \%$ of trees with $\mathrm{DBHOB}<30 \mathrm{~cm}$ ), but further work is needed to determine the suitability of these trees to be utilized for rotary veneer processing.

In order to help address this knowledge gap, a study was undertaken in selected native forests (hardwood and cypress) and processing facilities in Queensland, Australia. The study focused on estimates of volumes of smaller-diameter logs suitable and potentially available for rotary peeling using spindleless lathe technology.

\section{EXPERIMENTAL}

\section{Native Hardwood Assessments}

\section{Forest assessments}

For Crown hardwood forest assessments, inventory plots (randomly located) were established in Gurulmundi State Forest (-26.390881, 149.921707; $40 \mathrm{~km}$ north-west of Miles) and Allies Creek State Forest (-26.038059, 151.129623; $50 \mathrm{~km}$ south of Mundubbera) in Queensland, Australia (Fig. 1).

These forests are considered by leading industry experts to be representative of typical production native hardwood forests in this south-western Queensland region. Both forests were dominated by spotted gum (Corymbia citriodora). The forests had a history of selective timber harvesting and had previously received silvicultural treatment (pre1990), although no detailed records of the silvicultural history were available. 


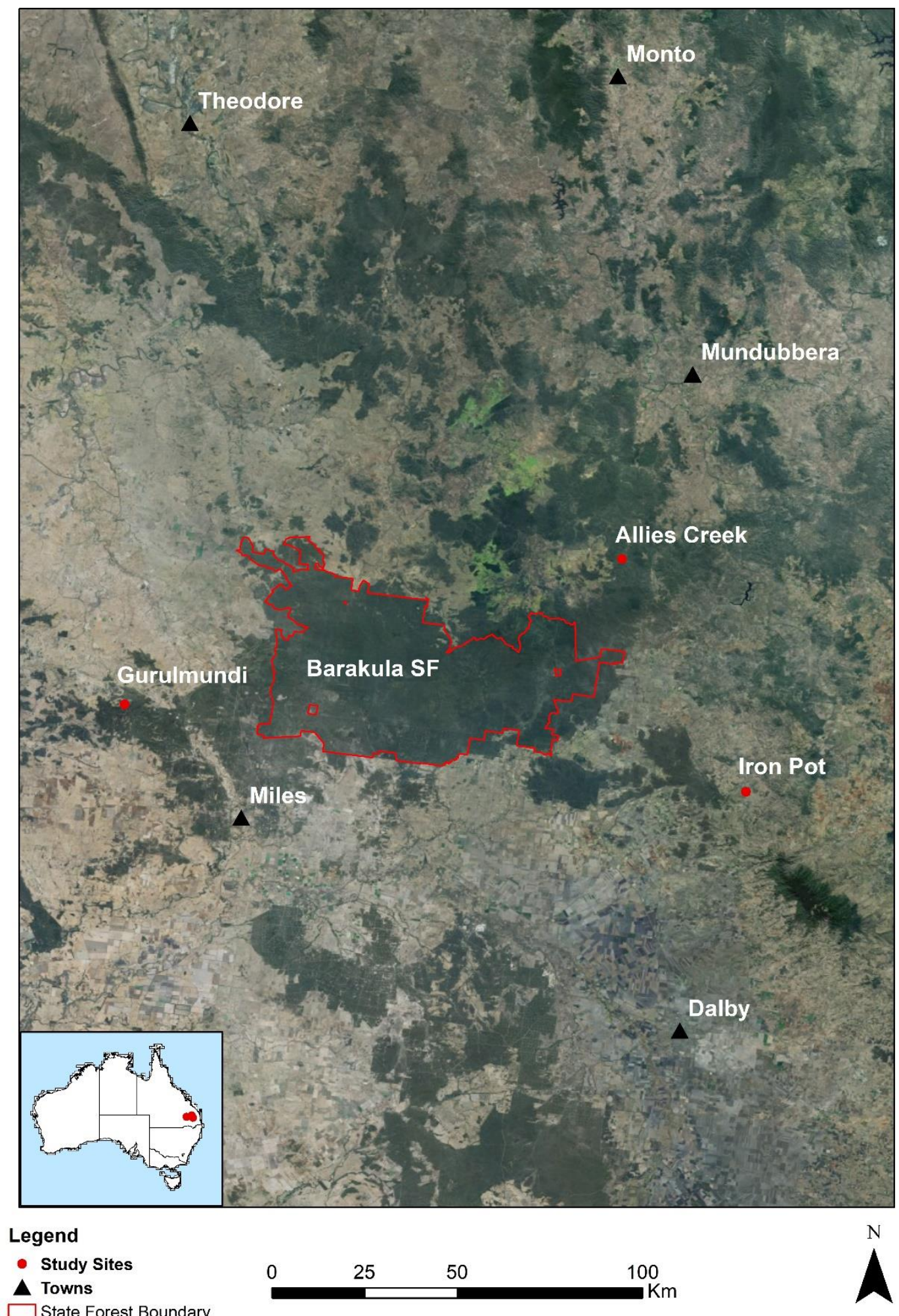

Fig. 1. Map showing the location of study sites 
In the Gurulmundi State Forest, ten inventory plots were established in a preharvest area, and tree measurements were recorded. Additionally, three inventory plots were set up in an area that had been harvested previously, and measurements were taken on only residual harvest material (logs remaining in the forest from merchandising/cross cutting and harvesting operations). In the Allies Creek State Forest, eight inventory plots were established in an area that had been previously harvested and, in this case, measurements were taken only on residual harvest material With the exception of one plot that was 0.3 hectares, all other plots in both State Forests were 0.25-hectare strip plots.

For the plots established in pre-harvest forest, all trees in the plot greater than 10 $\mathrm{cm}$ diameter at breast height over bark (DBHOB) were assessed for:

- DBHOB (converted to diameter at breast height under bark (DBHUB) using standard assumptions for bark thickness (e.g. for spotted gum sawlogs $-2 \mathrm{~cm}$ for $\log$ centre diameters up to $70 \mathrm{~cm}$ ) provided by Department of Agriculture and Fisheries, DAF);

- classification - according to the established tree marking guidelines for different log qualities in Queensland - sawlog, pole, girder, salvage, retained, habitat trees;

- merchantable log length and volume (using log length, small and large-end diameter under bark) according to established tree marking guidelines for different $\log$ qualities in Queensland - sawlog, poles, girders, and according to Table 1 for peelers;

- dimensions and number of merchantable logs within each stem.

Table 1. 'Small' Peeler Log Specifications Used for this Study

\begin{tabular}{|c|c|c|}
\hline Grade Criteria & Hardwood & Cypress \\
\hline Length & $\begin{array}{c}1.5 \text { to } 2.7 \mathrm{~m} \text { (with overcut } \\
\text { allowance) }\end{array}$ & $\begin{array}{c}1.5 \text { to } 2.7 \mathrm{~m} \text { (with overcut } \\
\text { allowance) }\end{array}$ \\
\hline Minimum SEDUB* & $18 \mathrm{~cm}$ & $16 \mathrm{~cm}$ \\
\hline Maximum SEDUB & $30 \mathrm{~cm}$ & $30 \mathrm{~cm}$ \\
\hline Core & $\begin{array}{l}\text { Defective core should not } \\
\text { exceed } 6 \mathrm{~cm} \text { in diameter }\end{array}$ & $\begin{array}{l}\text { Defective core should not } \\
\text { exceed } 6 \mathrm{~cm} \text { in diameter }\end{array}$ \\
\hline External defect & $\begin{array}{l}\text { No green limbs }>6 \mathrm{~cm} \text { in } \\
\text { diameter; no dry limbs }>3 \mathrm{~cm} \\
\text { in diameter. No more than one } \\
\text { bump (i.e. occluded limbs) on } \\
\text { visible half of the log within } \\
\text { each } 50 \mathrm{~cm} \text { length; no more } \\
\text { than one overgrowth (i.e. } \\
\text { insect or logging damage) on } \\
\text { visible half of the log within } \\
\text { each } 50 \mathrm{~cm} \text { length; fluting } \\
\text { acceptable where the hollows } \\
\text { do not extend into the centre } \\
\text { log diameter. }\end{array}$ & $\begin{array}{l}\text { No green limbs }>9 \mathrm{~cm} \text { in } \\
\text { diameter; no dry limbs }>4.5 \\
\mathrm{~cm} \text { in diameter. No more than } \\
\text { two bumps (i.e. occluded } \\
\text { limbs) on visible half of the log } \\
\text { within each } 50 \mathrm{~cm} \text { length; no } \\
\text { more than one overgrowth } \\
\text { (i.e. insect or logging damage) } \\
\text { on visible half of the log within } \\
\text { each } 50 \mathrm{~cm} \text { length; fluting } \\
\text { acceptable where the hollows } \\
\text { do not extend into the centre } \\
\text { log diameter. }\end{array}$ \\
\hline Maximum sweep & $1 / 7(14 \%)$ of the SEDUB & $1 / 7(14 \%)$ of the SEDUB \\
\hline Ovality/taper & $\begin{array}{l}\text { Log diameter } 18-32 \mathrm{~cm} \text { : } \\
\text { maximum difference between } \\
\text { longest and shortest axis }(\mathrm{cm}) \\
\text { ranging from } 2.2-3.8 \mathrm{~cm} .\end{array}$ & $\begin{array}{c}\text { Log diameter } 16-32 \mathrm{~cm} \text { : } \\
\text { maximum difference between } \\
\text { longest and shortest axis }(\mathrm{cm}) \\
\text { ranging from } 2.2-3.8 \mathrm{~cm} .\end{array}$ \\
\hline Spiral grain/grain & $\begin{array}{l}\text { No spiral grain, no excessive } \\
\text { free grain }\end{array}$ & $\begin{array}{l}\text { No spiral grain, no excessive } \\
\text { free grain }\end{array}$ \\
\hline
\end{tabular}

${ }^{*}$ Small-end diameter under bark (SEDUB) 
From the measured data, basal area $\left(\mathrm{m}^{2} / \mathrm{ha}\right.$, a measurement of tree density/ha expressed as the cross section $\left(\mathrm{m}^{2}\right)$ of all trees at breast height) was calculated.

The specifications used for peeler logs were similar to those currently used by a commercial peeler operation in Australia and are designed specifically for spindleless lathe processing of small hardwood logs. The specification used targeted logs that were of diameters less than that of logs typically used in a traditional sawmill operation. The log grading criteria used for peeler logs are shown in Table 1. Both pre and post-harvest assessments for peeler logs included all sections of the bole and crown.

For standing tree assessments in the field, not all the grade criteria outlined in Table 1 were applied. For example, the presence of internal defects such as a defective core was not counted. Therefore, standing tree assessments in this study were limited to those grade criteria that could be applied without harvesting and cross cutting of logs.

While this study focused on the use of small diameter logs - a size considered suitable for peeling using spindleless lathes currently in use in Australia - spindleless lathes can potentially peel logs up to $80 \mathrm{~cm}$ SEDUB. The specifications were intentionally adopted to focus on log sizes not typically used and/or less favorable in Australia for other mainstream products such as sawlogs, larger poles, and girders.

For the private forest assessments, four strip inventory plots $(0.2$ hectares; randomly located) were established in a private native hardwood forest at Ironpot $(-26.603370$, 151.430700; approximately 60 km south-west of Kingaroy, Queensland, Australia (Fig. 1)). This forest was considered by leading industry experts to be representative of typical private native forests in this region, although it is acknowledged that there is a great deal of variation in the productive condition of private native forests. The forest was dominated by spotted gum with an understory of wattle (Acacia spp.) and other miscellaneous noncommercial species. Key features regarding the management history of the site included:

- a history of selective harvesting over the last 60 years for sawlogs, poles and sleepers with more intense harvesting during periodic downturns in the agricultural industry;

- low volumes of sawlog quality stems at the time of assessments due to previous harvesting;

- a lack of recent silvicultural treatment - the forest was overstocked with smaller diameter stems and would benefit from silvicultural treatment to increase productivity;

- property also used for cattle grazing.

All trees in the plot greater than $10 \mathrm{~cm}$ DBHOB were assessed for:

- DBHOB (converted to DBHUB);

- merchantable log length and volume - for peelers only - according to specifications provided in Table 1.

\section{Cypress Pine Assessments}

All available cypress pine logs from Crown forests in Queensland that meet the study's small-diameter peeler log specification are already allocated within contracted long-term supply agreements with sawmills. For this reason, field work for the cypress pine component of the study focused only on the log resource being used by the sawmills. DAF advised that small-diameter peeler logs could only be sourced from the existing Crown sawlog allocations or from private forests. In order to collect data on cypress logs in mill yards that met the smaller-diameter peeler specification outlined in Table 1, assessments 
were undertaken at two cypress sawmills in south-western Queensland. The logs were predominantly sourced from a mixed-age forest within the Barakula State Forest in Queensland, Australia. This forest was considered by leading industry experts to be representative of typical cypress forests in this region. Assessments were taken on random selections of logs in the log yard. This included recording the dimensions and numbers of small-diameter peeler logs (in accordance with the specification given in Table 1) that could be merchandised from the logs.

\section{RESULTS AND DISCUSSION}

\section{Data from Plots Established Pre-harvest in Crown Native Hardwood Forest}

Table 2 shows the estimated quantities of logs for different products available from the Gurulmundi State Forest based on the inventory plots that were established pre-harvest. More than $99.9 \%$ of the log volume was spotted gum. Data are shown as estimated quantities available on a per hectare basis. Small-diameter peeler log estimates are based on the small and conservative size specifications adopted for this project (Table 1). Various scenarios for peeler availability were evaluated. These were:

- Scenario A - assuming that all trees are available for harvesting and disregarding the Code of practice for native forest timber production on the Queensland Parks and Wildlife Service (QPWS) forest estate (Code of Practice; Department of National Parks, Recreation, Sports and Racing (2014)) and other requirements concerning habitat and retained trees. This scenario was considered in order to demonstrate the maximum possible availability of peeler logs with no regulatory constraints applied. For example, some private land contains regrowth forest that can be managed without following the native forest practice code (Department of Natural Resources and Mines (2014): Managing a native forest practice: accepted development vegetation clearing code, see: https://www.qld.gov.au/ environment/land/vegetation/codes), where land is classed as Category $\mathrm{X}$ vegetation; Department of Environment and Resource Management 2010).

- Scenario B - assuming that all 'habitat' marked trees were unavailable for harvesting, however all other trees were available for harvesting.

- Scenario C - as currently commercially tree-marked by DAF for current harvesting and sale practices and in accordance with the Code of Practice - all trees marked 'habitat' and 'retained' are not available; however, trees marked for other products are available for rotary peeling in accordance with specifications in Table 1.

- Scenario D - as currently commercially tree-marked by DAF for current harvesting and sale practices and in accordance with the Code of Practice and logs intended for other products such as sawlogs and poles are not available for rotary peeling.

- Scenario E - assuming that all 'habitat' marked trees are unavailable for harvesting; however, all other trees are available as peelers as long as $50 \%$ of the basal area is maintained as per the basal area requirements in the Code of Practice. 
- Scenario F - assuming that all 'habitat' marked trees are unavailable for harvesting; logs intended for other products such as sawlogs and poles are not available for rotary peelings; however, some trees marked 'retained' can be harvested for peelers as long as $50 \%$ basal area is maintained as per the Code of Practice.

Further inventory work is required to take into account the variability that exists in native forests across Queensland; however Table 2 shows that under the most typical current scenario - scenario D - where current DAF tree marking guidelines and Code of Practice requirements are adhered to and logs already removed for sawlogs, poles, and girders are not available for peeling, very minimal quantities of small-diameter peeler logs $\left(0.3 \mathrm{~m}^{3} /\right.$ ha on average) were available from the Gurulmundi State forest. This reinforces information provided by DAF that based on current tree marking, harvesting, and sale practices that in order to supply small logs from Queensland Crown forests for peeling, they would mainly need to be diverted from other uses (e.g., some sawlogs allocated to rotary peeling). It is also a result of the small-diameter and conservative peeler log specifications adopted which excluded logs larger than $30 \mathrm{~cm}$ SEDUB.

However, considerable volumes of small peeler logs (around $10.5 \mathrm{~m}^{3} / \mathrm{ha}$ ) are contained mainly in the trees currently marked as 'retained' by DAF (refer to Scenarios A, $\mathrm{B}$ and $\mathrm{E}$ in Table 2). These trees are marked as retained for various reasons - including being required for future growth and subsequent selective harvesting events, a lack of markets for small-diameter logs, achieving a minimal residual basal area of 50\%, water course protection, recruitment habitat trees, and incidence of rare or threatened species. For this volume to be accessed for peelers, it would require adjustments to the harvesting and tree marking rules and/or modifications to the Code of Practice. Future supply of peeler logs from Crown forests in Queensland will also depend on Government policies surrounding native forest access and legislation relating to conservation of rare and threatened plants and animals. It is important to point out that removal of peeler logs is likely to influence future growth and yield of the forest, depending on the volumes and quality of the stems removed.

Interestingly in Scenario $\mathrm{C}$ - where assuming all Code of Practice requirements have been met and that only peeler logs are considered as the target product from trees marked for harvesting (for sawlogs, poles, girders, etc.) - very little log volume meets the requirements of small-diameter peeler logs - on average only around $0.8 \mathrm{~m}^{3} /$ ha (Table 2 ). This is mainly because the majority of the trees marked for sawlogs, poles, and girders in Queensland exceed the small-diameter specifications adopted for this study for peelers intended for processing with spindleless lathe technology. Therefore, by far the greatest volume of potential peeler logs as defined by this study, is contained in the 'retained' trees not currently suitable for sawlog, poles, or girders.

The minimal difference in peeler log volumes between Scenario A $\left(10.5 \mathrm{~m}^{3} / \mathrm{ha}\right)$ and Scenario B $\left(10.4 \mathrm{~m}^{3} / \mathrm{ha}\right)$ highlights that the habitat trees contained minimal quantities of logs suitable for small peelers. The only difference between Scenario A and B was in regard to harvesting access to habitat trees. Habitat trees tend to be larger trees, often with characteristics (e.g. defects, such as stem hollows) that make them unsuitable for harvesting for commercial uses such as sawlogs, poles, girders, or peelers. 
Table 2. Estimates of Log Volumes Available per Hectare from Plots Established in Pre-harvest Crown Native Hardwood Forest

\begin{tabular}{|c|c|c|c|c|c|c|c|c|c|}
\hline \multirow[t]{2}{*}{ Plot } & \multirow{2}{*}{$\begin{array}{c}\text { Average } \\
\text { DBHUB } \\
(\mathrm{cm})\end{array}$} & \multicolumn{6}{|c|}{ Quantity of Small Peeler Logs ( $\left.\mathrm{m}^{3} / \mathrm{ha}\right)$} & \multirow{2}{*}{$\begin{array}{l}\text { Quantity of } \\
\text { Poles } \\
\text { (m³/ha) }\end{array}$} & \multirow{2}{*}{$\begin{array}{l}\text { Quantity of } \\
\text { Sawlogs } \\
\left(\mathrm{m}^{3} / \mathrm{ha}\right)\end{array}$} \\
\hline & & $\begin{array}{c}\text { Scenario } \\
\text { A }\end{array}$ & $\begin{array}{c}\text { Scenario } \\
\text { B }\end{array}$ & $\begin{array}{c}\text { Scenario } \\
\text { C }\end{array}$ & $\begin{array}{c}\text { Scenario } \\
\text { D }\end{array}$ & $\begin{array}{c}\text { Scenario } \\
E\end{array}$ & $\begin{array}{c}\text { Scenario } \\
\mathrm{F}\end{array}$ & & \\
\hline 1 & 23.1 & 13.6 & 13.1 & 4.0 & 0 & 13.1 & 7.2 & 7.8 & 2.8 \\
\hline 2 & 25.1 & 11.1 & 11.1 & 0 & 0 & 11.1 & 8.7 & 0 & 17.9 \\
\hline 3 & 25.7 & 9.5 & 9.5 & 2.3 & 1.4 & 9.5 & 1.4 & 14.3 & 27.1 \\
\hline 4 & 21.8 & 11.5 & 11.5 & 0 & 0 & 11.5 & 9.6 & 5.7 & 14 \\
\hline 5 & 21.4 & 20.1 & 20.1 & 0 & 0 & 20.1 & 17.8 & 3 & 13.6 \\
\hline 6 & 34.6 & 10.9 & 10.9 & 0 & 0 & 10.9 & 0 & 20.3 & 27.5 \\
\hline 7 & 38.4 & 8.4 & 7.5 & 0 & 0 & 7.5 & 1.9 & 34.6 & 19.3 \\
\hline 8 & 34.2 & 9.8 & 9.8 & 1.7 & 1.7 & 9.8 & 1.7 & 8.4 & 16.5 \\
\hline 9 & 32.8 & 1.2 & 1.2 & 0 & 0 & 1.2 & 0 & 0 & 14.9 \\
\hline 10 & 25.3 & 9.1 & 9.1 & 0 & 0 & 9.1 & 2.1 & 0 & 11.8 \\
\hline Mean & 28.3 & 10.5 & 10.4 & 0.8 & 0.3 & 10.4 & 5.0 & 9.4 & 16.5 \\
\hline $\begin{array}{l}\text { Standard } \\
\text { Deviation }\end{array}$ & 6.1 & 4.7 & 4.7 & $\overline{1.4}$ & 0.7 & 4.7 & 5.7 & 11.1 & 6.9 \\
\hline
\end{tabular}


Scenarios B and E differed only in that for Scenario E, 50\% of the basal area was maintained as per the Code of Practice. These scenarios generated equivalent peeler log volumes, demonstrating that an average of $10.4 \mathrm{~m}^{3} /$ ha of peeler logs were available even if $50 \%$ of the basal area was maintained as well as habitat trees not being available for harvesting. Scenario F was the same as Scenario E with the exception that trees marked as sawlogs, poles, or girders were not available for access as peeler logs. Even with these restrictions, Scenario F generated an average peeler log volume of $5 \mathrm{~m}^{3} / \mathrm{ha}$.

Table 2 shows that relatively high volumes of sawlogs and poles were available from the Gurulmundi forest plots, around $16.5 \mathrm{~m}^{3} /$ ha and $9.4 \mathrm{~m}^{3} /$ ha respectively. Normally, as a rough rule of thumb, in these forest types in Queensland, an area is considered economically viable to harvest if the estimated sawlog volume is at least $3 \mathrm{~m}^{3} / \mathrm{ha}$. However, this can vary depending on many factors including forestry region, market demand for sawlogs and other products, productivity, and the quality of the forest.

Volume availability is only one important factor in assessing forest resources for potential peeler log supply. Another important factor is the range of log lengths and diameters available. In order to best demonstrate the variation in these parameters from the field work undertaken, data from Scenario B are used as an example. The log length distribution for the small-diameter peeler logs under Scenario B shows that $90 \%$ of the peeler logs are $2.7 \mathrm{~m}$ or longer (Fig. 2). This data is for maximum merchantable lengths recovered from each stem in the forest at the harvest site, therefore not for the final log lengths for input into the peeling operation. Figure 3 shows the SEDUB distribution for the peeler logs (for the maximum merchantable length logs from each tree at the harvest site) under Scenario B - the majority of the peeler logs are in the range from 19 to $24 \mathrm{~cm}$. However, the SEDUB distribution would change after the full-length logs have been cut to final lengths for peeling. The peeler log size distribution results for Scenario B are a positive outcome given that these are log dimensions that most spindleless lathes can process.

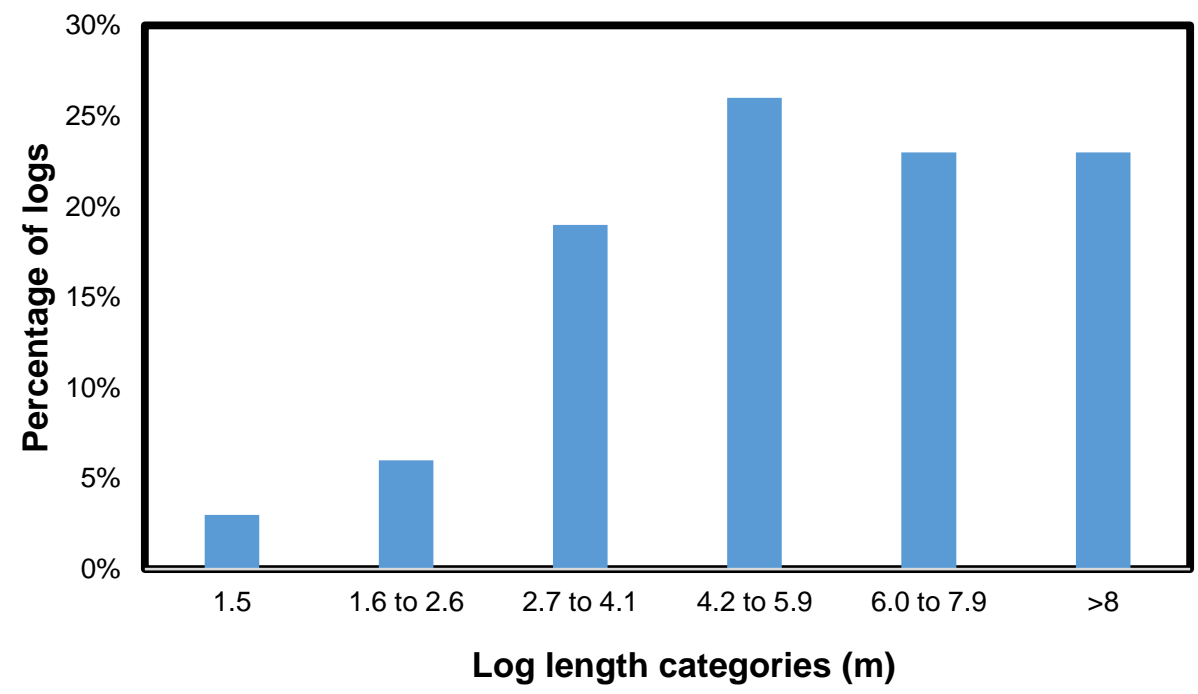

Fig. 2. Peeler log length distribution under Scenario B (for maximum merchantable lengths from trees) 


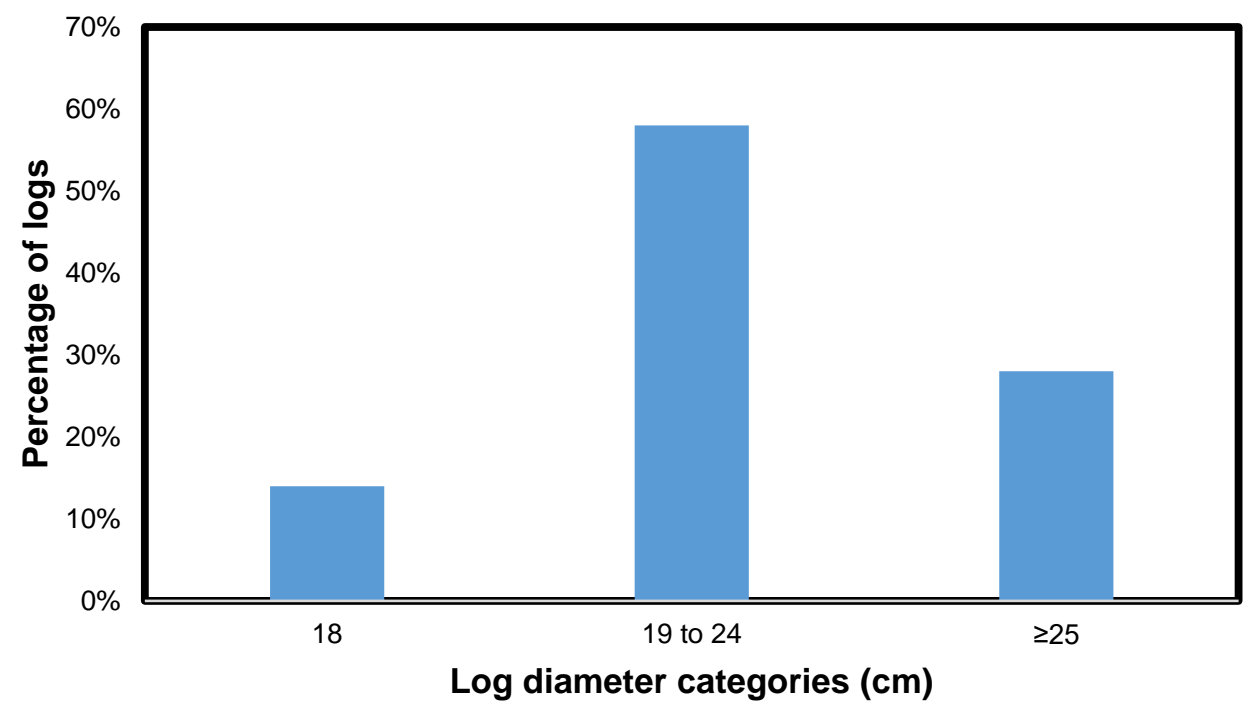

Fig. 3. Peeler log diameter (SEDUB) distribution under Scenario B (for maximum merchantable lengths from trees)

\section{Data from Plots Established Post-harvest in Crown Native Hardwood Forest}

Inventory plots were also established in previously logged forest to establish how much of the residual logging residue from harvesting operations would meet the smalldiameter peeler specifications provided in Table 1 . Very little of the logging residue was suitable for peelers; on average only $0.6 \mathrm{~m}^{3} / \mathrm{ha}$ was available (Table 3). Also more than $85 \%$ of this volume was in log lengths less than $2.7 \mathrm{~m}$ and most of this peeler volume was less than $25 \mathrm{~cm}$ SEDUB (Figs. 4 and 5).

Table 3. Estimates of Log Volumes Available Per Hectare from Plots Established in Post-harvest Crown Native Forest Hardwood Logging Residue

\begin{tabular}{|c|c|}
\hline Plot Number & Total Peeler Volume $\left(\mathrm{m}^{3} / \mathrm{ha}\right)$ \\
\hline 11 (Allies Creek) & 1.7 \\
\hline 12 (Allies Creek) & 0.3 \\
\hline 13 (Allies Creek) & 0 \\
\hline 14 (Allies Creek) & 0.2 \\
\hline 15 (Allies Creek) & 0.2 \\
\hline 16 (Allies Creek) & 1.1 \\
\hline 17 (Allies Creek) & 0.8 \\
\hline 18 (Allies Creek) & 0.9 \\
\hline 19 (Gurulmundi) & 0.4 \\
\hline 20 (Gurulmundi) & 0.4 \\
\hline 21 (Gurulmundi) & 0.3 \\
\hline Mean & $\mathbf{0 . 6}$ \\
\hline Standard Deviation & 0.5 \\
\hline
\end{tabular}




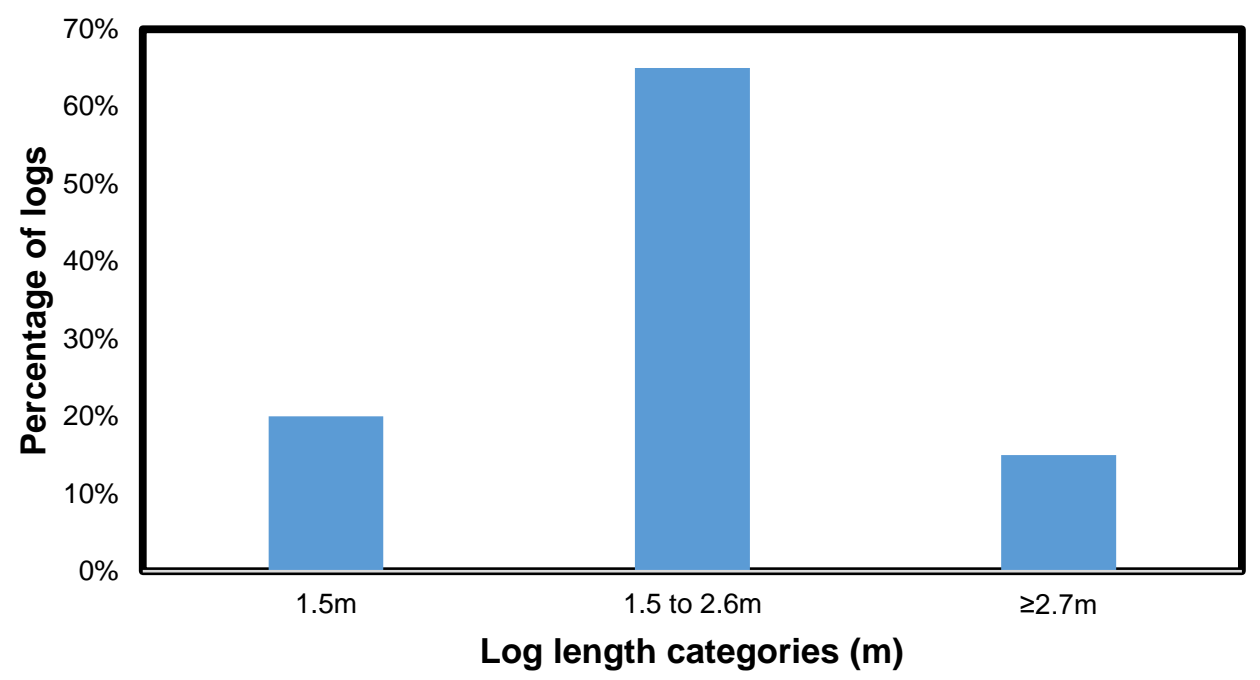

Fig. 4. Peeler log lengths distribution from post-harvest logging residue

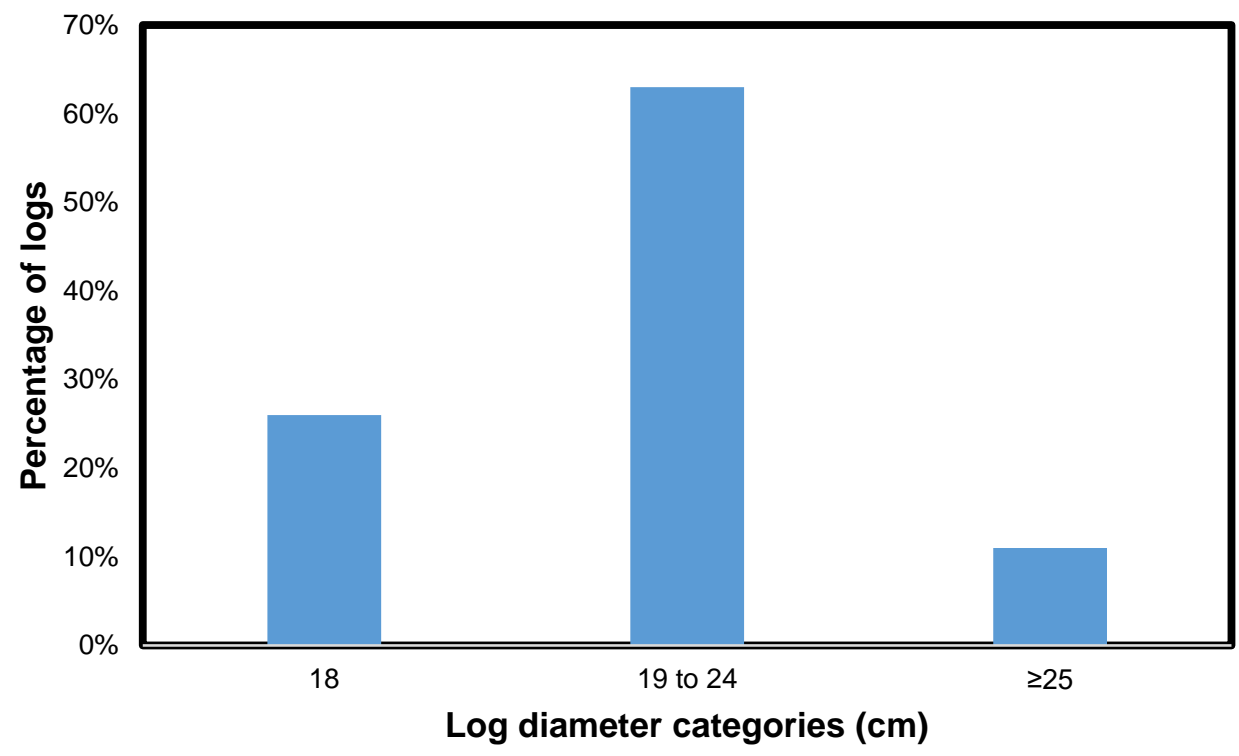

Fig. 5. Peeler log diameter (SEDUB) distribution from post-harvest logging residue

\section{Data from Plots Established Pre-harvest in Private Native Hardwood Forest}

Table 4 summarises the estimated small-diameter peeler volumes based on the assessments undertaken in the measurement plots at a private native hardwood forest site. These assessments were undertaken assuming that all standing trees if suitable were also available for harvesting as peelers. Significant volumes of small peeler logs were available from this private native forest (on average $\sim 14 \mathrm{~m}^{3} / \mathrm{ha}$ ). This was backed up by a recent analysis of the private native forest resource in the region (Lewis et al., unpublished). At a series of 20 properties (and 156 permanent monitoring plots) the mean volume of hardwood logs with a DBHOB of between 20 and $30 \mathrm{~cm}$ and with a log length of at least $1.5 \mathrm{~m}$ was $8.4 \mathrm{~m}^{3} /$ ha (standard error $=0.86$ ). However, this preliminary assessment only considered logs that were likely to produce a future conventional product (e.g. sawlog or pole) and did 
not specifically assess small diameter trees for peeler logs. As there is often a high density of stems $<30 \mathrm{~cm}$ DBHOB in private native forest (Lewis 2018), the volume of logs that could potentially be used for peeling is likely higher than this average value. Nevertheless, net peeler log recovery would reduce after application of relevant regulations and consideration of other product types for future harvests. Additional assessments are needed to determine how representative the plots assessed in the current study are of the larger private forest resource in Queensland, which is known to be highly variable (Ryan and Taylor 2006).

According to the Private Forestry Service Queensland (PFSQ) (S. Ryan, Personal Communication, May, 2017) much of the private native forest in Queensland is not growing at an optimal rate due to overstocking and is in need of silvicultural treatment to promote tree growth. One impediment to silvicultural treatment of these forests is that the associated cost (e.g. around $\$ 350$ per hectare) is unable to be offset due to the current lack of viable markets for thinning material (i.e. when silvicultural thinning does take place, thinned material is usually left in the forest as waste). Small-diameter peeler logs could represent a viable market opportunity enabling the cost-effective silvicultural treatment of these forests. However, future changes in legislation (e.g. changes to the native forest code) could have an impact on potential availability of peeler logs from this resource.

Table 4. Estimates of Peeler Log Volumes Available per Hectare from Plots Established in Pre-Harvest Private Native Hardwood Forest

\begin{tabular}{|c|c|}
\hline Plot Number & $\begin{array}{c}\text { Total Peeler Volume } \\
\left(\mathrm{m}^{3} / \mathrm{ha}\right)\end{array}$ \\
\hline 1 & 16.2 \\
\hline 2 & 14.2 \\
\hline 3 & 15.8 \\
\hline 4 & 9.0 \\
\hline Mean & $\mathbf{1 3 . 8}$ \\
\hline Standard Deviation & $\mathbf{3 . 3}$ \\
\hline
\end{tabular}

\section{Data from Cypress Pine Assessments}

The field work undertaken determined that around $60 \%$ of the logs in cypress pine sawmills met the small-diameter peeler log specification as outlined in Table 1. If this conversion factor is applied to the annual cypress log supply volumes from DAF then around 75,000 $\mathrm{m}^{3}$ / year of Crown cypress pine logs would be potentially suitable for peeling in the south-western region of Queensland. It is important to note that using these logs for peeling would reduce cypress volumes available for sawing by $60 \%$ because according to DAF, there is no additional cypress log volume available that isn't already allocated to sawing. Crown forest cypress peeler logs would only be available from the south-western region of Queensland. For cypress pine, economic studies are needed to determine whether peeling will provide greater returns than sawing.

Another possibility for increasing supplies of cypress pine peeler logs and also reducing forest waste is the utilization of short length cypress log sections that are left in the forest. These sections result from 'butting' or 'topping' of defective sections in cypress logs due to defects such as yellow doze (decayed wood with a yellowish colour), heart rot (decay in the middle of the log), windshake (cracking in wood due to strong winds), excessive knots, bends (lengthwise curvature of the $\log$ ), and other defects. Current practices usually result in sections that are $1 \mathrm{~m}$ or less. Given that some spindleless lathes 
can use short lengths to $<1.5 \mathrm{~m}$, there may be some potential in using these short lengths for peeling, if field practices were adjusted to consider minimum peeler log lengths (i.e. $1.3 \mathrm{~m}$ and $2.7 \mathrm{~m}$ ). Further inventory work to investigate this possibility is recommended. Markets for the resulting short-length veneer would also need to be developed.

\section{CONCLUSIONS}

1. Many factors influence the potential quantities of small-diameter peeler logs available from native forests in Queensland. These include but are not limited to:

- Specifications adopted regarding grade quality and size requirements

- Politics, Government log supply agreements, policies and regulations including Code requirements in both crown native forests and private native forests

- Alternative current or future uses of logs of the same quality

- Economic and market conditions, e.g. increased or decreased harvesting of private forests during economic downturns or upturns in the agricultural industry (as log timber harvesting helps provide cashflow).

2. Substantial volumes of logs (on a per hectare basis) meeting the small peeler log specifications adopted for this study are potentially available from native forests in Queensland. However, in the case of hardwood, most of this volume is currently left 'standing' in the forest for the following reasons:

- Part of the future growing stock for the next and subsequent selective harvesting events

- Current lack of demonstrated viable markets for this size and quality

- Current tree marking, harvesting and sale practices focusing on mainstream larger log size products such as sawlogs, poles and girders

- Code of Practice and other regulations.

3. Current native hardwood forest sales are focused on products such as sawlog, poles and girders because of existing market demand. It is possible that if demand for small peeler logs commenced, then there may be a shift in tree marking and harvesting procedures to facilitate supply and sales of the smaller peeler logs. This would need to consider economic viability for processors and forest managers.

4. Selective harvesting practices are universally applied in private native hardwood forests in Queensland; however, a history of crop tree harvesting (i.e. high-grading) without follow up silvicultural treatment has tended to leave many forest areas in a relatively low commercial productivity state (DAF, 2016). One reason that these forests are not being silviculturally treated (in addition to key factors such as harvest security and Government legislation) is due to a lack of demonstrated markets for the small thinned stems. Harvesting these logs to supply spindleless lathe peeling operations could offer a viable financial solution that would contribute to improving the long-term forest health and productivity.

5. This paper discusses the results of a preliminary resource assessment. Further inventory work is necessary to determine how representative the study findings are to native forests across Queensland and to improve estimates of likely volumes available. 
Additionally the study considered only small-diameter logs ( $<30 \mathrm{~cm}$ SEDUB). Given spindleless lathes are able to also process much larger logs, additional analysis including larger log sizes (assuming diversion from other uses such as sawlogs) would significantly increase the volume of logs suitable for rotary veneer processing. Further processing, product and market research could also result in a new set of log specifications being developed that could significantly change peeler log availability estimates.

\section{ACKNOWLEDGMENTS}

The authors are grateful to the Queensland Government, Department of Agriculture and Fisheries (DAF), the Forest and Wood Products Australia, Big River Group, Austral Plywoods, Parkside Group, Hurford Wholesale, Engineered Wood Products Association of Australasia, Timber Queensland and HQ Plantations for their support and participation in the overarching project, of which this study formed a part. Mr John Huth (DAF), Mr. Bill Gordon (DAF), Mrs. Jane Siebuhr (DAF), Mr. Sean Ryan (PFSQ), Mr. Chris Opperman (DAF), Mr. Neil Reinke (DAF), Mr. Stuart Olive (DAF), Mr. Trevor Beetson (DAF), Mr. Nathaniel Lindsay (DAF), Mr. John Ludlow (DAF), Dr. Kerrie Catchpoole (DAF), Mr. Jim Burgess (DAF), Mr. Neville Smith (Parkside), Parkside Harvesting and Haulage contractors (Glen, James, Trevor, and John Rassy) and Mr. Simon BoivinDompierre (USC) are acknowledged for their contribution in the form of methodology development, background data, forest access, log selection, harvesting and haulage arrangements. Mister Peter Clark and the Hurford Wholesale Chinchilla sawmill team are acknowledged for their assistance with the cypress pine field work. Mister Eric Littee, Mr. Dan Field, and Mr. Jock Kennedy (DAF) are acknowledged for their assistance with the tree and log assessment work.

\section{REFERENCES CITED}

Belleville, B., Redman, A., Chounlamounty, P., Phengthajam, V., Xiong, S., Boupha, L., and Ozarska, B. (2018). "Potential of veneer peeled from young eucalypts in Laos," BioResources 13(4), 7581-7597. DOI: 10.15376/biores.13.4.7581-7594

Department of Environment and Resource Management (2010). Guide to Exemptions under the Vegetation Management Framework. Brisbane: Vegetation management and Land Planning, Brisbane, Australia.

Department of National Parks, Recreation, Sports and Racing (State of Queensland) (2014). "Code of practice for native forest timber production on the QPWS (Queensland Parks and Wildlife Service) forest estate," Brisbane, Australia.

Department of Natural Resources and Mines (2014). Managing a Native Forest Practice: A Self-Assessable Vegetation Clearing Code, Brisbane, Australia.

Jay, A. (2017). Condition of NSW North Coast Private Forest, Report to NSW

Department of Primary Industries, Orange, Australia.

Leggate, W., R. L. McGavin, and H. Bailleres (eds.) (2017). A Guide to Manufacturing

Rotary Veneer and Products from Small Logs, Australian Centre for International

Agricultural Research, Canberra, Australia.

Lewis, T. (2018). Private Native Forest Management. South-eastern Queensland. 
Department of Agriculture and Fisheries, Queensland, (https://publications.qld.gov.au/dataset/private-native-forest-resource-extent-andcondition/resource/56cf2996-f5e5-4553-a607-3ca799601bf0, accessed 18 June 2019.

Lewis, T., Venn, T., Francis, B., Ryan, S., Brawner, J., Cameron, N., Kelly, A., Menzies, T. and Schulke, B. (unpublished). Improving productivity of the private native forest resource in southern Queensland and northern New South Wales. Report prepared for and submitted to Forest and Wood Products Australia.

McGavin, R. L, Bailleres, H., Lane, F., Blackburn, D., Vega, M., and Ozarska, B. (2014a). "Veneer recovery analysis of plantation eucalypt species using spindleless lathe technology," BioResources 9(1), 613-627. DOI: 10.15376/biores.9.1.613-627

McGavin, R. L, Bailleres, H., Lane, F., Fehrmann, J. and Ozarska, B. (2014b). "Veneer grade analysis of early to mid-rotation plantation eucalyptus species in Australia," BioResources 9(4), 6565-6581. DOI: 10.15376/biores.9.4.6565-6581

McGavin, R. L, Bailleres, H., Hamilton, M., Blackburn, D., Vega, M., and Ozarska, B. (2015a). "Variation in rotary veneer recovery from Australian plantation Eucalyptus globulus and Eucalyptus nitens," BioResources 10(1), 313-329. DOI: 10.15376/biores.10.1.313-329

McGavin, R. L., Bailleres, H., Fehrmann, J., and Ozarska, B. (2015b). "Stiffness and density analysis of rotary veneer recovered from six species of Australian plantation hardwoods," BioResources 10(4), 6395-6416. DOI: 10.15376/biores.10.4.6395-6416

McGavin, R. L., and Leggate, W. (2019). "Comparison of processing methods for smalldiameter logs: Sawing versus rotary peeling,” BioResources 14(1), 1545-1563. DOI: 10.15376/biores.14.1.1545-1563

Peng, Y., Washusen, R., Xiang, D., Lan, J., Chen, S., and Arnold, R. (2014). "Grade and value variations in Eucalyptus urophylla x E. grandis veneer due to variations in initial plantation spacings," Australian Forestry 77, 39-50. DOI: 10.1080/00049158.2013.877415

Ryan, S., and Taylor, D. (2006). Sustainable Native Forest Management. Case Studies in Managing Private Native Forest in South-East Queensland, Department of Primary Industries and Fisheries, Queensland, Australia.

Article submitted: July 18, 2019; Peer review completed: September 18, 2019; Revised version received: October 11, 2019; Accepted: October 12, 2019; Published: October 16, 2019.

DOI: 10.15376/biores.14.4.9485-9499 